\title{
RECOGNITION OF THE ANDORRA RED CROSS
}

Geneva, 24 March 1994

\author{
Circular No. 577 \\ To the Central Committees of the \\ National Red Cross and Red Crescent Societies
}

\section{Ladies and Gentlemen,}

We have the honour of informing you that the International Committee of the Red Cross has officially recognized the Andorra Red Cross. This recognition. which took effect on 24 March 1994, brings to 162 the number of National Societies that are members of the International Red Cross and Red Crescent Movement.

The Andorra Red Cross applied for recognition by the ICRC on 10 August 1993. In support of its application it submitted various documents, including a report on its activities in 1992 and the text of its statutes. Decree No. 507/ V promulgated by the General Council on 21 March 1980 recognized the Society on the basis of the Geneva Conventions as the only Red Cross Society in Andorra, a voluntary aid organization auxiliary to the public authorities and authorized to extend its activities throughout the country's territory.

The various documents submitted, which were examined by both the ICRC and the Secretariat of the International Federation of Red Cross and Red Crescent Societies in the framework of the Joint ICRC/Federation Commission for National Society Statutes, showed that the ten conditions for recognition of a new National Society had been fulfilled.

On 10 August 1993, Andorra declared its accession to the four Geneva Conventions of 12 August 1949, to which it became party on 17 March 1994.

During a visit to the Society, representatives of the ICRC and the Federation ascertained that the Society has an infrastructure enabling it to work throughout Andorra. It is currently engaged in activities in the following areas: first-aid 
training, health education, ambulance services, assistance to the elderly or persons in need, and foreign aid programmes, particularly in the health field.

The President of the Andorra Red Cross is Mr Serafí Miro Bernado. The address of the Society's headquarters, which are located in Andorra la Vella, is as follows:

\title{
Andorra Red Cross \\ Prat de la Creu 22 \\ Andorra la Vella \\ Andorra
}

The International Committee of the Red Cross is pleased to welcome the Andorra Red Cross into the International Red Cross and Red Crescent Movement. It hereby accredits and commends it to all other National Societies, and wishes it every success in continuing and developing its humanitarian work.

With high consideration.

\author{
For the International Committee \\ OF THE RED CROSS
}

\section{Cornelio Sommaruga}

President 